\title{
ASPIRATION PNEUMONIA IN PATIENTS WITH STROKE, NORTHEAST NIGERIA
}

\author{
${ }^{1}$ Watila M.M., ${ }^{1}$ Nyandaiti Y.W., ${ }^{2}$ Balarabe S.A., ${ }^{1}$ Bakki B., ${ }^{3}$ Alkali N., ${ }^{4}$ Ibrahim A., ${ }^{1}$ Tonde E., \\ ${ }^{1}$ Chiroma I.
}

${ }^{1}$ University of Maiduguri Teaching hospital, PMB 1414, Maiduguri, Borno State. Nigeria;

${ }^{2}$ Usman Danfodio University Teaching Hospital, Sokoto State. Nigeria;

${ }^{3}$ National Hospital, Abuja, Nigeria;

${ }^{4}$ Federal Medical Centre, Azare, Bauchi State, Nigeria.

All correspondence to: Dr. Watila M. Musa.

University of Maiduguri Teaching hospital,

P.M.B 1414. Maiduguri, Borno State. Nigeria.

Telephone: +2348095208857

Email:watilamusa@yahoo.com

Objectives: Aspiration pneumonia is a common complication in patients with stroke, having a negative influence on morbidity and mortality. This study sought to assess the frequency of aspiration pneumonia and the independent predictors for its development among Nigerian patients with stroke.

Methods: Five hundred and twenty-four stroke patients were prospectively enrolled during the study period at the University of Maiduguri Teaching Hospital, Maiduguri, from January 2005 and May 2011. All patients who developed aspiration pneumonia during hospital stay and follow-up were recorded. A student's t-test and a Pearson chi-square analysis was used to compare baseline characteristics of subjects who developed aspiration pneumonia and those who did not. A multiple logistic regression was used to assess the independent predictors of aspiration pneumonia. We also recorded the rate of deaths and duration hospital stay within this period.

Results: Aspiration pneumonia occurred in 65 (12.4\%) of our stroke patients, A univariate analysis showed that patients with aspiration pneumonia were older $(\mathrm{P}<0.001)$, had a lower Glasgow coma score on presentation $(\mathrm{P}<0.001)$, were more likely to have swallowing $(\mathrm{P}<0.001)$ and speech problems $(\mathrm{P}=0.003)$. They were also more likely to have severe stroke (NIHSS, $\mathrm{P}<0.001)$ and disability $(\mathrm{mRDS}, \mathrm{P}<0.001$; Barthel' ADL index, $\mathrm{P}<0.001)$ both on admission and discharge. They had a higher 60 - day fatality $(75.4 \%$ versus $9.4 \% ; \mathrm{P}<0.001)$ and a lower duration of stay $(25.3 \pm 17.5$ versus $34.6 \pm 28.3 ; \mathrm{P}=0.01)$. Factors associated with the development of aspiration pneumonia are; Age $>60$ years (OR, 2.3; 95\% CI, 1.37 3.91; $\mathrm{P}=0.002)$; Initial GCS $\leq 12$ (OR, 4.5; 95\% CI, $2.60-8.00 ; \mathrm{P}<0.001)$; dysphagia (OR, 12.1; 95\% CI, 6.50 - 22.70; $\mathrm{P}<0.001)$; dysphasia (OR, 2.2; 95\% CI, $1.29-3.70 ; \mathrm{P}=0.004)$; admission $\mathrm{mRDS} \geq 4$ (OR, 4.1; 95\% CI, 1.43 - 11.50; $\mathrm{P}=0.008)$; admission NIHSS $\geq 11$ (OR, 2.5; 95\% CI, $1.34-4.66 ; \mathrm{P}=0.004)$; admission Barthel' ADL index $<30$ (OR, 16.9; 95\% CI , $4.07-70.29$; $\mathrm{P}<0.001$ ).

Conclusion: Aspiration pneumonia is a common complication in our stroke patients. Decline in consciousness, swallowing and speech difficulties, and severe strokes are associated with the development of aspiration pneumonia.

Keywords: Stroke, Complications, Aspiration pneumonia, Nigeria, Sub-Saharan

Africa.

\section{Introduction}

Pneumonia associated with stroke is a common complication and a major cause of disability and death [1, 2, 3]. The frequency of pneumonia in acute stroke may reach up to $42 \%$, with aspiration pneumonia contributing significantly to these pneumonias [4]. Aspiration pneumonia contributes to the development of worse stroke, poor functional outcome and longer duration of stay $^{5}$; by inducing hypoxaemia, hyperpyrexia, and systemic inflammatory response, which are deleterious in strokes [6,7]. The risk of 
aspiration pneumonia in stroke patients has been linked to several factors which include; weakness of swallowing muscles and swallowing apraxia [8], altered consciousness [9], severe strokes [2, 10], recumbency [11], poor oral health [12], older age [9, 10], speech problems [10], large infarct, multiple strokes, and brainstem strokes [2, 8, 13]. Aspiration in normal persons usually provokes protective violent cough, which is depressed in stroke patients [8].

Only limited data are available regarding poststroke complications in Nigeria; and to the best of our knowledge only one available study examined gastrointestinal complications in stroke patients [14]. Therefore, we sought to study the frequency of aspiration pneumonia and the predictors for developing aspiration pneumonia in patients treated for stroke at a university teaching hospital.

\section{Methods}

The study was conducted at the University of Maiduguri teaching hospital (UMTH), a major referral center in northeast Nigeria. The study was conducted concurrently with a prospective study on medical complications in stroke in this center [15], between January 2005 and May 2011. There were 524 consecutive patients enrolled for the study, the subjects included those with first-ever and recurrent strokes; irrespective of stroke subtype. Stroke was defined based on the World Health Organisation (WHO) criteria [16].

Information on patients demographic and baseline characteristics were recorded, including: age, sex, stroke risk factors, swallowing, dysphasia and dysarthria.

All patients who developed pneumonia attributable to aspiration while on admission or seen during follow up were recorded. Aspiration pneumonia was diagnosed based on the criteria by Langhorne et al. [17], these include respiratory symptoms and signs, auscultatory respiratory crackles, chest radiographic evidence or new purulent sputum.

Dysphagia/swallowing problems were assessed using a simple bed side swallowing test in which increasing quantity of water was given, starting with about a spoon full, and swallowing was assessed for coughing, choking or breathing difficulty [18].

Patients' conscious level was assessed using the Glasgow coma score (GCS). Stroke severity was measured using the national institutes of health stroke score (NIHSS), while disability was measured using the modified Rankin disability score (mRDS) and the Barthel's activity of daily living (ADL) score, these indices were assessed both on admission and discharge, and the measurement was done by a member of the team or a trained intern.

The duration of hospital stay and 60-day fatality were recorded for all patients.

Consent was sought from all patients or their surrogates, and the study was approved by the Hospital's Ethics committee.

Statistical analysis: A univariate analysis (Student's t-test for continuous variable and Pearson's $\chi^{2}$ for categorical variable) was used to compare baseline stroke characteristics, risk factors, GCS, indices of stroke severity (NIHSS, mRDS and Barthel's ADL, on admission and discharge), duration of hospital stay, and 60dafality, between those with and those without aspiration pneumonia. A multiple logistic regression was used for those factors that were significant on univariate analysis to determine independent predictors and odds ratio of factors that influence the development of aspiration pneumonia. Data were analyzed using Statistical Package for the Social Sciences software (SPSS, version 16.0). Statistical significance was accepted as $\mathrm{P} \leq 0.05$.

\section{Results}

Table 1 shows the baseline characteristics of patients. Aspiration pneumonia occurred in 65 $(12.4 \%)$ patients. Comparing characteristics between those who had aspiration pneumonia and those who did not; those with aspiration pneumonia where more likely to be older $(\mathrm{P}<0.001)$, to have a lower GCS on admission $(\mathrm{P}<0.001)$, to have dysphagia $(\mathrm{P}<0.001)$, and speech problems $(p=0.003)$. There was no significant sex difference in the development of aspiration pneumonia. Stroke patient with aspiration pneumonia were also more likely to have a severe stroke (NIHSS, $\mathrm{P}<0.001$ ) and disability on admission (mRDS, $\mathrm{P}<0.001$; Barthel' ADL index, $\mathrm{P}<0.001$ ), while on discharge, patients with aspiration pneumonia were more likely to have poorer recovery (NIHSS, $\mathrm{P}<0.001$ ), and are more likely to be disabled on discharge (mRDS, $\mathrm{P}<0.001$; Barthel' ADL index, 
$\mathrm{P}<0.001)$. Patients with aspiration pneumonia had a higher 60 - day fatality $(75.4 \%$ versus $9.4 \%$; $\mathrm{P}<0.001$ ), with a lower duration of hospital stay (25.3 \pm 17.5 versus $34.6 \pm 28.3 ; \mathrm{P}=0.01$ )

Table 2 shows the factors that were independently associated with the development of aspiration pneumonia. These includes: Age > 60 years (OR, 2.3; 95\% CI, $1.37-3.91 ; \mathrm{P}=0.002)$; Initial $\mathrm{GCS} \leq 12$ (OR, 4.5; 95\% CI, 2.60 - 8.00; $\mathrm{P}<0.001$ ); dysphagia (OR, 12.1; 95\% CI, $6.50-$ 22.70; $\mathrm{P}<0.001)$; dysphasia (OR, 2.2; 95\% CI, 1.29 - 3.70; $\mathrm{P}=0.004)$; admission $\mathrm{mRDS} \geq 4$ (OR, 4.1; 95\% CI, 1.43 - 11.50; $\mathrm{P}=0.008)$; admission NIHSS $\geq 11 \quad(\mathrm{OR}, \quad 2.5 ; \quad 95 \% \quad \mathrm{CI}, 1.34$ - 4.66; $\mathrm{P}=0.004$ ); admission Barthel' ADL index $<30$ (OR, 16.9; 95\% CI , $4.07-70.29$; $\mathrm{P}<0.001)$.

\section{Discussion}

Aspiration pneumonia is a common complication, occurring in $12.4 \%$ of our study population. Our study showed that increased risk of aspiration pneumonia is associated with increasing age, severe stroke, a lower conscious level, swallowing and speech difficulties. Patients with aspiration pneumonia were more likely to die from the complication. This study revealed that there was no sex difference in pneumonia occurring during a stroke, this is in keeping with the study by Sellars et al. [10], although a different study [19] reported a reduced risk of pneumonia in females.

The percentage of patients with aspiration pneumonia in our study is similar to other studies $[11,20]$, higher than other studies [1, 21, 22], and lower than other studies $[10,17,23]$. These discrepancies in incidence may be due to differences in definition, identification and diagnosis of patients with pneumonia. Our study did not include other causes of pneumonia not attributed to aspiration; this may have reduced the percentage. Our percentage appears lower, and may be that we missed some of the patient, when aspiration is of small volume it may be difficult to diagnose [9].

Our study showed that those with pneumonia are less likely to survive beyond the earlier post stroke period than other patients, the effect of pneumonia on stroke mortality has been widely reported in several studies [2, 3, 5, 9], reasons given include; decreased pulmonary oxygen saturation, increase in temperature, worsening of strokes and its role in increasing mediators of inflammations [4, 6, 7]. Studies have reported that those with aspiration pneumonia had a longer duration of hospital stay [2, 24], but our study reported a shorter duration of stay in patients with aspiration pneumonia, and this may be due to the excess early post-stroke fatality.

There is increased risk of pneumonia in patients with dysphagia in this study. Studies have shown that patients with dysphagia were more likely to have pulmonary complications, and it is in itself an independent predictor of mortality and longer duration of hospital stay $[10,25,26]$. The study by Smithard et al. [25] and Reynolds et al. [24] showed that patients with swallowing problem had a higher risk of pulmonary complications and advised that bedside assessment of swallowing is of use in identifying patients at risk of developing complications, and noted that the value of routine screening with videofluoroscopy may be better in detecting swallowing problems, especially for some patients in whom swallowing difficulty may not be clinically obvious.

The risks of aspiration pneumonia have been related with multiple lesion and vertebrobasilar stroke signifying that this area control swallowing reflex and its dynamics [2]. This is a limitation this study had, since only a negligible patient had neuroimaging [15].

Despite our routine bedside swallowing assessment, our patients or their surrogates hardly agree to a nasogastric tube insertion. In our environment there is a belief that NG tube insertion signifies a poor prognosis, and so except for very ill patients, NG tube insertions are usually objected to by patients and their caregivers, in patients with dysphagia. Although, the insertion of an NG tube may be beneficial in patients with dysphagia [27]; some studies infer that insertion of nasogastric tube offers little protection or may make patients prone to aspiration pneumonia $[28,29]$.

Some of the limitations of the study are: lack of objective swallowing analysis using videofluorographic studies [18]; most of our patient had no neuroimaging, and so we could not assess the effect of stroke subtype, area and size of lesion with swallowing problems and pneumonia. We did not study the influence of nasogastric tube insertion in aspiration pneumonia.

In Conclusions, this study suggests that aspiration pneumonia is a common complication; its 
development is associated with altered consciousness, swallowing and speech difficulties, and severe strokes. Those with aspiration pneumonia are more likely to die within 60 - days. This study should help in designing future stroke care by assessing swallowing difficulties in our stroke patients and to reorganize our process of care.

\section{REFERNCES}

1. Ingeman A, Andersen G, Hundborg HH, Svendsen ML, Johnsen SP. Processes of Care and Medical Complications in Patients With Stroke. Stroke 2011; 42: 167-172.

2. Hilker R, Poetter C, Findeisen N, Sobesky J, Jacobs A, Neveling M, Heiss W-D. Nosocomial Pneumonia after Acute Stroke. Implications for Neurological Intensive Care Medicine. Stroke. 2003; 34: 975-981.

3. Silver F, Norris J, Lewis A, Hachinski V. Early mortality following stroke: a prospective review. Stroke 1984; 15: 494.

4. Marik PE. Aspiration Pneumonitis and Aspiration Pneumonia. N Engl J Med 2001; 344: 665-671.

5. Bounds JV, Wiebers DO, Whisnant JP, Okazaki H. Mechanisms and timing of deaths from cerebral infarction. Stroke 1981; 12: 474477.

6. Grau AJ, Buggle F, Schnitzler P, Spiel M, Lichy C, Hacke W. Fever and infection early after ischemic stroke. J Neurol Sci. 1999; 171: 115120.

7. Gee JM, Kalil A, Shea C, Becker KJ. Lymphocytes: Potential Mediators of Postischemic Injury and Neuroprotection. Stroke 2007; 38: 783-788.

8. Daniels SK. Swallowing Apraxia: A Disorder of the Praxis System? Dysphagia 2000; 15: 159-166.

9. DeLegge MH. Aspiration Pneumonia: Incidence, Mortality, and At-Risk Populations.

J Parenter Enteral Nutr 2002; 26: S19-25.

10. Sellars C, Bowie L, Bagg J, Sweeney MP, Miller H, Tilston J, Langhorne P, Stott DJ. Risk Factors for Chest Infection in Acute Stroke. A Prospective Cohort Study. Stroke 2007; 38: 2284
2291.

11. Kelley RE, Vibulsresth S, Bell L, Duncan RC. Evaluation of Kinetic Therapy in the Prevention of Complications of Prolonged Bed Rest Secondary to Stroke. Stroke 1987; 18: 638642.

12. Langmore SE, Terpenning MS, Schork A, Chen Y, Murray JT, Lopatin D, Loesche WJ. Predictors of aspiration pneumonia: how important is dysphagia? Dysphagia. 1998; 13: 6981.

13. Daniels SK, Foundas AL. Lesion localization in acute stroke patients with risk of aspiration. J Neuroimag 1999; 9: 91-98.

14. Otegbayo JA, Talabi OA, Akere A, Owolabi MO, Owolabi LF, Oguntoye OO. Gastrointestinal complications in stroke survivors. Trop. Gastroenterol 2006; 27: 127-30.

15. Watila MM, Nyandaiti YW, Balarabe SA, Ibrahim A, Alkali NH, Gezawa ID, Bwala SA. Medical complications among stroke patients at the University of Maiduguri Teaching Hospital, Northeastern Nigeria. Journal of Medicine and Medical Science. 2012; 3: 189-194.

16. WHO Monica project, Principal investigators. The World Health Organization Monica project (monitoring trends and determinants in cardiovascular disease) a major international collaboration. J. Clin Epid 1988; 41: 105-114.

17. Langhorne P, Stott DJ, Robertson L, MacDonald J, Jones L, McAlpine C, Dick F, Taylor GS, Murray G. Medical Complications after Stroke, A Multicenter study. Stroke. 2000; 31:1223.

18. Daniels SK, McAdam CP, Brailey K, Foundas AL. Clinical assessment of swallowing and prediction of dysphagia severity. Am J Speech Lang Pathol. 1997; 6: 17-24.

19. Tirschwell DL, Kukull WA, Longstreth Jr. WT. Medical Complications of Ischemic Stroke and Length of Hospital Stay: Experience in Seattle, Washington. J Stroke and Cerebrovasc Dis 1999; 8: 336-343.

20. Indredavik B, Rohweder G, Naalsund E, Lydersen S. Medical Complications in a Comprehensive Stroke Unit and an Early Supported Discharge Service. Stroke 2008; 39: 414-420. 
21. Tong X, Kuklina EV, Gillespie C, George MG, Medical Complications among Hospitalizations for Ischemic Stroke in the United States From 1998 to 2007. Stroke 2010; 41: 980986.

22. Roth EJ, Lovell L, Harvey RL, Heinemann AW, Semik P, Diaz S. Incidence of and Risk Factors for Medical Complications during Stroke Rehabilitation. Stroke 2001; 32: 523-529.

23. Johnston KC, Li JY, Lyden PD, Hanson SK, Feasby TE, Adams RJ, Faught RE Jr, Haley EC Jr. Medical and neurological complications of ischemic stroke: experience from the RANTTAS trial. RANTTAS Investigators. Stroke 1998; 29: 447- 453.

24. Reynolds PS, Gilbert L, Good DC, Knappertz VA, Crenshaw C, Wayne SL, Pillbury $\mathrm{D}$, Tegeler CH. Pneumonia in Dysphagic Stroke Patients: Effect on Outcomes and Identification of High Risk Patient. Neurorehabil Neural Repair 1998; 12: 115-121.

25. Smithard DG, O'Neill PA, Park C, Morris J, Wyatt R, England R, Martin DF. Complications and Outcome after Acute Stroke. Does Dysphagia Matter? Stroke 1996; 27: 1200-1204.

26. Altman KW, Yu G-P, Schaefer SD. Consequence of Dysphagia in the Hospitalized Patient. Impact on Prognosis and Hospital Resources. Arch Otolaryngol Head Neck Surg 2010; 136: 784-789.

27. Difficulty Swallowing After Stroke. American Stroke Association, a division of American Heart Association. www.strokeassociation.org/presenter. 2010; 38: 35-42.

28. Dziewas R, Ritter M, Schilling M, Konrad C, Oelenberg S, Nabavi, D Stogbauer F, Ringelstein E, and Ludemann P. Pneumonia in acute stroke patients fed by nasogastric tube. J Neurol Neurosurg Psychiatry 2004; 75: 852-856.

29. Wang HE, Cook LJ, Chang CH, Yealy DM, Lave JR. Outcomes after out-of-hospital endotracheal intubation errors. Resuscitation 2009; 80: 50-55.

\section{БОЛЬНЫХ С ИНСУЛЬТОМ В СЕВЕРОВОСТОЧНОЙ НИГЕРИИ}

\author{
Ватила М.М. ${ }^{1}$, Няндаити Й.В. ${ }^{1}$, Баларабе \\ С.А. ${ }^{2}$, Бакки Б. ${ }^{1}$, Алкали Н. ${ }^{3}$, Ибрагим А. ${ }^{4}$, \\ Тонде Е. ${ }^{1}$, Кирома И. ${ }^{1}$ \\ ${ }^{1}$ Университет клинической больницыь \\ Майдугури, РМВ 1414, Майдугури, итат \\ Борно. Нигерия; \\ ${ }^{2}$ Университет клинической больниць Усман \\ Данфодио, итат Сокото, Нигерия; \\ ${ }^{3}$ Национальная больница, Абужа, Нигерия; \\ ${ }^{4}$ Федеральный медицинский центр, Азаре, \\ штат Баучи, Нигерия.
}

Аспирационная пневмония является частым осложнением у больных с инсультом и оказывает негативное влияние на уровень заболеваемости и смертности. Это исследование ставило целью оценить частоту аспирационной пневмонии и выявить независимые прогностические факторы для ее развития среди нигерийских пациентов с инсультом.

Методы: 524 больных с инсультом проспективно изучены в течение периода исследования в Университете клинической больницы Майдугури, (январь 2005 года-май 2011 года). Все пациенты, у которых во время пребывания в больнице развилась аспирационная пневмония последующим были исследованы. Множественная логистическая регрессия была использована для оценки независимых предикторов аспирационной пневмонии. Также были изучены уровень смертности и продолжительность пребывания больных в течение этого периода.

Вывод: Аспирационная пневмония являлось частым осложнением у пациентов, перенесших инсульт. У больных с тяжелом инсультом снижение уровня сознания, нарушения глотания и речи были связаны с развитием аспирационной пневмонии.

Ключевые слова: инсульт, осложнения, Аспирационная пневмония, Нигерии, СубСахарская Африка.

İNSULTLU XəSTəLəRDə ASPIRASION 


\section{PNEVMONIYA, ŞIMAL-ŞəRQİ NIGGERIYA}

Vatila M.M. ${ }^{1}$, Nyandaiti Y.W. ${ }^{1}$, Balarabe S.A. ${ }^{2}$, Bakki B. ${ }^{1}$, Alkali N. ${ }^{3}$, Ibrahim A. ${ }^{4}$, Tonde E. ${ }^{1}$, Chiroma I. ${ }^{1}$

${ }^{1}$ Maiduguri kliniki xəstəxanasının universiteti, PMB 1414, Maiduguri, Borno ştatı. Nigeriya; ${ }^{2}$ Usman Danfodio kliniki xəstəxanasının universiteti, Sokoto ștatı. Nigeriya; ${ }^{3}$ Mərkəzi xəstəxana, Abuja, Nigeriya;

${ }^{4}$ Fedral tibbi mərkəz, Azare, Bauçi ştatı, Nigeriya.

Aspirasion pnevmoniya insultlu xəstələrdə ümumi ağırlaşmalardandır və xəstələnmə və ölümə mənfi təsir göstərir. Təqdim edilmiş tədqiqat işi Nigeriyalı insultlu xəstələr arasında aspirasion pnevmoniyanın rastgəlinmə tezliyinin və yaranmasının müstəqil prediktorlarını
Tədqiqatın metodu. 524 insultlu xəstə Mayduquri kliniki xəstəxanasında prospektiv olaraq tədqiq edilmişdir (Yanvar 2005-ci il-may 2011-ci il). Xəstəxanada müalicə edilərkən və sonra aspirasion pnevmoniya inkişaf etmiş xəstələrin hamısı tədqiqata cəlb edilmişdir. Aspirasion pnevmoniyanın müstəqil prediktorlarının qiymətləndirilməsi üçün çoxsaylı loqistik reqressiya metodundan istifadə edilmişdir. Həm də bu dövrdə ölümün səviyyəsi və stasionar günlərin sayı tədqiq edilmişdir.

Nəticə. Bizim insultlu xəstələrdə aspirasion pnevmoniya tez-tez rast gəlinən ağırlaşmadır. Huşun vəziyyətinin alaqaranlıqlaşması, udma və nitq pozulmaları və ağır insultlar aspirasion pnevmoniyanın inkişafı ilə əlaqəlidir.

Açar sözlər: insult, ağırlaşma, aspirasion pnevmoniya, Nigeriya, Sub-Saxara Afrikası. araşdırmışdır. 
Table 1. Baseline Characteristics of study subjects

\begin{tabular}{|c|c|c|c|}
\hline & \multicolumn{3}{|c|}{ Aspiration Pneumonia } \\
\hline & Yes $(n=65)$ & No $(n=459)$ & $P$ value \\
\hline$\overline{\text { Age } \pm \text { SD }}$ & $62.2 \pm 10.5$ & $55.6 \pm 13.1$ & $<0.001 *$ \\
\hline Males & $39(60.0)$ & $287(62.5)$ & 0.694 \\
\hline Females & $26(40.0)$ & $172(37.5)$ & \\
\hline Hypertension & $58(89.2)$ & $398(86.7)$ & 0.571 \\
\hline Diabetes mellitus & $5(7.7)$ & $48(10.5)$ & 0.489 \\
\hline Previous stroke & $10(15.4)$ & $50(10.9)$ & 0.287 \\
\hline Alcohol & $5(7.7)$ & $39(8.5)$ & 0.827 \\
\hline Smoking & $4(6.2)$ & $31(6.8)$ & 0.856 \\
\hline TIA & $3(4.6)$ & $25(5.5)$ & 0.780 \\
\hline Dysphagia & $28(43.1)$ & $27(5.9)$ & $<0.001 *$ \\
\hline Dysphasia & $38(58.5)$ & $180(39.2)$ & $0.003 *$ \\
\hline Dysarthria & $3(4.6)$ & $17(3.7)$ & 0.720 \\
\hline Glasgow coma score (admission) & $12.2 \pm 3.4$ & $14.1 \pm 2.3$ & $<0.001 *$ \\
\hline \multicolumn{4}{|l|}{ Stroke severity (mean) } \\
\hline NIHSS Admission & $22.1 \pm 7.7$ & $12.8 \pm 5.9$ & $<0.001 *$ \\
\hline NIHSS Discharge & $34.6 \pm 12.8$ & $10.3 \pm 11.6$ & $<0.001 *$ \\
\hline mRDS on admission & $4.4 \pm 0.6$ & $3.8 \pm 0.7$ & $<0.001 *$ \\
\hline mRDS on discharge & $4.9 \pm 1.4$ & $3.1 \pm 1.4$ & $<0.001 *$ \\
\hline Barthel's ADL on admission & $9.5 \pm 12.9$ & $27.6 \pm 21.8$ & $<0.001 *$ \\
\hline Barthel's ADL on discharge & $11.6 \pm 27.2$ & $57.2 \pm 28.2$ & $<0.001 *$ \\
\hline Mean SBP & $153.3 \pm 32.7$ & $158.2 \pm 33.6$ & 0.260 \\
\hline Mean DBP & $94.9 \pm 19.4$ & $98.0 \pm 19.4$ & 0.228 \\
\hline Mean RBS & $7.6 \pm 3.8$ & $7.7 \pm 5.0$ & 0.877 \\
\hline Cholesterol & $4.6 \pm 1.0$ & $4.9 \pm 1.3$ & 0.075 \\
\hline Mean WBC & $7.5 \pm 3.2$ & $6.8 \pm 3.4$ & 0.118 \\
\hline Duration of hospital stay & $25.3 \pm 17.5$ & $34.6 \pm 28.3$ & $0.010 *$ \\
\hline 60-day fatality & $49(75.4)$ & $43(9.4)$ & $<0.001 *$ \\
\hline
\end{tabular}

Student's t-test for continuous variable and Pearson's $\chi^{2}$, (with Upton's adjustment) for categorical variable.

$*$ P-value $\leq 0.05$ 
Table 2. Independent predictors for the development of Aspiration pneumonia

\begin{tabular}{lllc}
\hline Independent variable & OR & 95\% CI & P-value \\
\hline Age $>60$ & 2.3 & $1.37-3.91$ & 0.002 \\
Elevated white blood cell count $>8 \times 10^{9} / \mathrm{L}$ & 1.4 & $0.70-3.80$ & 0.344 \\
Initial Glascow coma scale $\leq 12$ & 4.5 & $2.60-8.00$ & $<0.001$ \\
Dysphagia & 12.1 & $6.50-22.70$ & $<0.001$ \\
Dysphasia & 2.2 & $1.29-3.70$ & 0.004 \\
Admission mRDS $\geq 4$ & 4.1 & $1.43-11.50$ & 0.008 \\
Admission NIHSS $\geq 11$ & 2.5 & $1.34-4.66$ & 0.004 \\
Admission Barthel's ADL index $<30$ & 16.9 & $4.07-70.29$ & $<0.001$ \\
\hline
\end{tabular}

Logistic regression analysis of variables, $\mathrm{P}<0.05$ 